\title{
Demographic and Clinical Charachteristics of Immune Thrombocytopenia in Sudanese Children
}

\author{
Fathelrahman Elawad Ahmed ${ }^{1, *}$ Egbal Hussien Younies ${ }^{2}$ \\ ${ }^{1}$ Department of Pediatrics, Alneelain University, Khartoum, Sudan \\ ${ }^{2}$ Ministry Of health, Khartoum, Sudan
}

\begin{abstract}
Abstract: The demographic and clinical profile of immune thrombocytopenia is well reported in the literature but was not reported before from Sudan.

Method: A retrospective chart review was performed for all children diagnosed as immune thrombocytopenia (ITP) in three major hospitals over six and half years period. 47 patients were identified. The median age was 6.5 years. Males and females were equally affected. A preceding upper respiratory infection was present in one third of patients. Epistaxis was the commonest presenting feature (87.2\%). Gastrointestinal bleeding, gross hematuria and subconjunctival bleeding were the presenting features in $36.2 \%, 19.1 \%$ and $4.3 \%$ respectively. Ecchymosis and petechiae were the commonest clinical signs, seen in $46.8 \%$ and $29.8 \%$ respectively. Chronic ITP constituted one third of patients. Steroids were the first line of treatment. No death was encountered.

Conclusion: ITP in Sudanese children has similar features as those reported before, however, gross hematuria and gastrointestinal bleeding were seen more frequent in them.
\end{abstract}

\section{Introduction}

Immune thrombocytopenia (ITP), an acquired hematological disorder, is due to production of auto-antibodies against platelets that leads to isolated thrombocytopenia provided other causes of thrombocytopenia such as drugs, infections, malignancy, or other autoimmune diseases are absent $[1,2]$. It commonly affects children between one and seven years of age[3,4]. A preceding history of infection is found in about $60 \%$ of paediatric cases [5]. The following bleeding manifestations were reported in children with ITP, cutaneous $(86 \%)$, oral $(19 \%)$ and nasal $(20 \%)[3,6,7]$. The diagnosis of ITP in children is one of exclusion. In patients with suspected ITP Laboratory investigations are simple and include a complete blood count and peripheral blood smear. Bone marrow examination is no longer considered necessary [8]. Management options for newly diagnosed childhood ITP include; observation only, steroids, the use of intravenous immunoglobulin (IVIG), anti-D immunoglobulin, each alone or in combination [2,5]. Splenectomy may be of benefit for children who develop chronic ITP [5]. Other useful drugs in children with chronic ITP are Rituximab and thrombopoietin receptors agonist (TPO) $[9,10]$.

The objective of this study is to describe for the first time the demographics and clinical characteristics of Sudanese children with ITP.

\section{Patients and Methods}

This was an observational, case finding, hospital based; retrospective study. It was carried out at Gaafar Ibn Auf, Omdurman and Ahmed Gassim pediatric teaching hospitals involving patients who were admitted during the period from 1st of January 2007 to 30 of June 2012.

Inclusion criteria: All children with age from birth-15 year who were diagnosed as ITP .

Exclusion criteria: history of ingestion of drugs known to cause thrombocytopenia, organomegally, abnormal coagulation screening, abnormal liver enzymes and history to suggest connective tissue diseases. Data was collected by reviewing the records .The retrieved data contained demographic characteristics, clinical history, clinical examination, laboratory data, medications used and outcome. The data was displayed as figures, range, median and per centage .It was analyzed using SSPS (version 16 ). $\mathrm{P}$ value $<0.05$ was used to indicate statistical significance. The study was approved by the ethical committee of the concerned hospitals .Platelets count below $150 \times 10^{9} / 1$ defined thrombocytopenia. Thrombocytopenia present for less than six months was used to define acute ITP and thrombocytopenia present for more than six months was used to define chronic ITP.

\section{Results}

A total of 47 patients were identified, $32(68.1 \%)$ patients with acute ITP and 15(31.9\%) patients with chronic ITP. The median age for patients with acute ITP was 6.5 years (range $0.5-14$ years) and for patients with chronic ITP was 9.5 years (range 2.5-14 years). There were $17(53.1 \%)$ females children with acute ITP and 8 (53.3\%) female children with chronic ITP $(\mathrm{P}=0.989)$. History of febrile illness 1-2 weeks prior to presentation was common in patients with acute $\operatorname{ITP}(86.7 \%$ vs $13.3 \%$ P 0.043$)$. The mean platelets count at presentation was $\left(13.93 \pm 11.74 \times 10^{9} / 1\right)\left(\right.$ range $\left.1.0-98 \times 10^{9} / 1\right)$ Table 1. Mean hemoglobin level was $120 \pm 38$ gram/L, mean leucocyte count was $6.5 \pm 2.8 \times 10^{9} / 1$ (table 1 ). The Peripheral blood picture was normal in all patients. The demographic and clinical features of the study population are shown in table 1, age at presentation of patients with acute and chronic ITP is shown in table 2. The frequency of

"Corresponding Author: Dr. Fathelrahman Elawad Ahmed, Department of Pediatrics, Alneelain University, Khartoum, Sudan; Tel: 0966543998590; E-mail: fatahmed1@gmail.com

Citation: Elawad Ahmed F, Younies EH (2016) Demographic and Clinica Charachteristics of Immune Thrombocytopenia in Sudanese Children. Int J Pediatr Neonat Care 2: 117. doi: https://doi.org/10.15344/2455-2364/2016/117

Copyright: (C) 2016 Elawad Ahmed et al. This is an open-access article distributed under the terms of the Creative Commons Attribution License, which permits unrestricted use, distribution, and reproduction in any medium, provided the original author and source are credited. 
Citation: Elawad Ahmed F, Younies EH (2016) Demographic and Clinical Charachteristics of Immune Thrombocytopenia in Sudanese Children. Int J Pediatr Neonat Care 2: 117. doi: https://doi.org/10.15344/2455-2364/2016/117

Page 3 of 4

\begin{tabular}{|c|c|c|}
\hline Characteristics & $\mathrm{No}(\%)$ & $P$ value \\
\hline \multicolumn{3}{|l|}{ Gender: } \\
\hline $\begin{array}{c}\text { Males } \\
\text { Females }\end{array}$ & $\begin{array}{l}22(46.1 \%) \\
25(53.9 \%)\end{array}$ & 0.989 \\
\hline Median age(years) & 6.5(Range:0.5-14) & \\
\hline $\begin{array}{l}\text { Febrile illness (1-2wks) before } \\
\text { diagnosis }\end{array}$ & $15(31.9 \%)$ & \\
\hline History of previous vaccination & None & \\
\hline Epistaxis & $41(87.2 \%)$ & \\
\hline Hematemesis & $11(23.4 \%$ & \\
\hline Gum bleeding & $10(21.3 \%)$ & \\
\hline Gross hematuria & $4(19.1 \%) \mathrm{S}$ & \\
\hline Melena & $6(12.8 \%)$ & \\
\hline Subconjunctival hemorrhage & $2(4.3 \%)$ & \\
\hline $\begin{array}{l}\text { Clinical signs: } \\
\text { Petechiae } \\
\text { Ecchymosis } \\
\text { Hematomas }\end{array}$ & $\begin{array}{l}14(29.8 \%) \\
22(46.8 \%) \\
4(8.5 \%)\end{array}$ & \\
\hline $\begin{array}{l}\text { Organomegaly/ } \\
\text { lymphadenopathy }\end{array}$ & None/none & \\
\hline Mean Hemoglobin(Grams/L) & $120 \pm 38.0$ & \\
\hline Mean leukocyte count $\left(x 10^{9} / 1\right)$ & $6.5 \pm 2.8 \times 10^{9}$ & \\
\hline Mean platelet count $\left(\mathrm{x} 10^{9} / \mathrm{l}\right)$ & $\begin{array}{l}(13.93 \pm 1.74)(\text { range } \\
1.0-98)\end{array}$ & \\
\hline
\end{tabular}

Table 1: Demographic, clinical and laboratory characteristics of study population (n 47).

\begin{tabular}{|c|c|c|c|}
\hline \multirow[t]{2}{*}{ Age } & \multicolumn{2}{|c|}{ Variety } & \multirow[t]{2}{*}{$P$ value } \\
\hline & Acute ITP & chronic ITP & \\
\hline \multirow[t]{3}{*}{0 - 5 years } & 13 & 2 & \\
\hline & & & 0.065 \\
\hline & $40.6 \%$ & $13.3 \%$ & \\
\hline \multirow[t]{3}{*}{5 - 10 years } & 13 & 6 & \\
\hline & & & 0.072 \\
\hline & $40.6 \%$ & $40.0 \%$ & \\
\hline \multirow[t]{3}{*}{10 - 15 years } & 6 & 7 & \\
\hline & & & 0.004 \\
\hline & $18.8 \%$ & $46.7 \%$ & \\
\hline \multirow[t]{2}{*}{ Total } & 32 & 15 & \\
\hline & $100.0 \%$ & $100.0 \%$ & \\
\hline
\end{tabular}

Table 2: Age distribution of children with acute and chronic ITP $(\mathrm{N}=$ 47).

bleeding episodes in the study population is shown in Table 3. Those who had their bone marrow examined were reported to have increased megakaryocytes. Antinuclear antibodies (ANA), Direct Coomb's Test (DAT) and HIV screening were negative in all tested children (Table 4). A family history of bleeding was present in $29.8 \%$ of patients. 14 patients $(29.9 \%)$ received no treatment, 16 patients $(34.0 \%)$ were treated with prednisolone, $3(6.3 \%)$ received methylprednisolone, 8 patients (7.1\%)received methylprednisolone and prednisolone 2 (4.2\%) had intravenous immunoglobulin (IVIG). Cyclosporine,

dexamethasone and methotrexate were given to one patient $(2.1 \%)$ after failure to respond to steroids and IVIG. Splenectomy was done in $2(13.3 \%)$ patients with chronic ITP. Discussion: This is the first report on clinical profile of ITP in Sudanese children; it used the old definition and classification of the disease because that was the diagnosis given before the recent terminology. In this study patients with acute ITP were younger than those with chronic ITP, an observation similar to what had been reported before $[11,12]$. Males and females were equally affected, this is similar to what had been mentioned before in many series.[3,11-14]. However, in a report of 1784 children with newly diagnosed ITP males predominated [7]. A viral illness or vaccination commonly precede childhood ITP[15-17]. In this study no patient had vaccination that preceded the thrombocytopenia but one third of patients had a febrile illness 1-2 weeks before the onset of the disease. The number of patients who had an antecedent febrile illness in this study is similar to that reported from Pakistan [18] but less compared to other reports where about two third of patients had a prior viral illness $[4,19,20]$. The absence of history of vaccination or an infection shortly before the onset of ITP significantly correlates with a disease chronic course [21]

\begin{tabular}{|l|l|l|l|}
\hline & Acute ITP & chronic ITP & P value \\
\hline $1-5$ times & 30 & 5 & 0.002 \\
& $93.8 \%$ & $33.3 \%$ & \\
\hline $5-10$ times & 2 & 7 & 0.001 \\
& $6.3 \%$ & $46.7 \%$ & \\
\hline$>10$ times & 0 & 3 & 0.000 \\
& $.0 \%$ & $20.0 \%$ & \\
\hline Total & 32 & 15 & \\
\hline & $100.0 \%$ & $100.0 \%$ & \\
\hline
\end{tabular}

Table 3: Frequency of bleeding episodes per year in children with acute and chronic ITP patients.

\begin{tabular}{|l|l|l|l|}
\hline & $\begin{array}{c}\text { Acute ITP } \\
\text { No (\%) }\end{array}$ & $\begin{array}{c}\text { Chronic ITP } \\
\text { No(\%) }\end{array}$ & $\begin{array}{c}\text { Total } \\
\text { (total n= 47) }\end{array}$ \\
\hline $\begin{array}{l}\text { Bone marrow } \\
\text { aspiration }\end{array}$ & $11(23.4 \%)$ & $13(27.7 \%)$ & $24(51.1 \%)$ \\
\hline $\begin{array}{l}\text { Antinuclear } \\
\text { antibodies(ANA) }\end{array}$ & $3(6.4 \%)$ & $12(25.5 \%)$ & $15(31.9 \%)$ \\
\hline $\begin{array}{l}\text { Direct coomb's test } \\
(\text { DAT) }\end{array}$ & $5(10.6 \%)$ & $12(25.5 \%)$ & $17(36.9 \%)$ \\
\hline HIV $^{*}$ & $3(6.4 \%)$ & $12(25.5 \%)$ & $15(31.9 \%)$ \\
\hline
\end{tabular}

Table 4: Diagnostic tests performed in the study patients.

*The results of these tests were negative

The cutaneous manifestations of ITP were reported to be present in almost all patients $[18,22,23]$, our patients were not an exemption. Epistaxis was present in the majority of patients $(87 \%)$. This is different from what had been reported in the literature where epistaxis occurred in $24-33 \%$ of patients [18,24,25]. Gross hematuria, considered a major hemorrhage or complication of ITP [25,26], was common in this study unlike the rare incidence $(\leq 2.4 \%)$ reported in the literature [27-29]. Microscopic hematuria,which was reported to occur in $27 \%$ of patients in one report [30], was not determined in this study. Hematuria was considered to be a warning sign for intracranial hemorrhage $(\mathrm{ICH})$ [31]. Despite the frequent occurrence of hematuria in this study we did not encounter a single case with ICH). Hematemesis and melena were common in this study compared tothe rare occurrence (up to $2.0 \%$ ) reported in the literature [27,28,31]. 
Citation: Elawad Ahmed F, Younies EH (2016) Demographic and Clinical Charachteristics of Immune Thrombocytopenia in Sudanese Children. Int J Pediatr Neonat Care 2: 117. doi: https://doi.org/10.15344/2455-2364/2016/117

Page 3 of 4

This high incidence of hematemesis cannot be attributed to swallowed blood since none of our patients had severe epistaxis that required intervention like nasal packing. Subconjunctival hemorrhage in ITP was not reported before in children, even in adults we encountered a single case, presented with subconjunctival hemorrhage, reported in the ophthalmology literature [32]. A family history of thrombocytopenia was reported in $2 \%$ of children [ 7]. In this study a family history of bleeding was noted in almost one third of patients; whether thrombocytopenia was the caused or not was not determined. The meal platelets count was $9.0 \times 10^{9} / 1$. This is akin to that reported form Korea [33]. Almost two third of patients had a platelet count which was below $10.0 \mathrm{X} 10^{9} / \mathrm{l}$, a count considered to predict severe bleeding [34].

The ASH 2011 evidence-based practice guidelines for immune thrombocytopenia stated that: "a bone marrow examination is no longer considered necessary at diagnosis." Also it stated that: "We found insufficient evidence to recommend or suggest the routine use of antiplatelet, antiphospholipid, and antinuclear antibodies... etc." [8]. In this study bone marrow examination was done in $51 \%$ of patients and the findings were consistent with the diagnosis of ITP. This rate is similar to the rate reported by Kim et al. [35]. In a study from Pakistan $64.1 \%$ has a bone marrow examination and the findings were consistent with ITP [18].

Steroids were the first line and main stay of therapy for acute ITP in this series. This result was similar to what had been reported by a survey done in south Africa in which steroids were still the first option [36]. Besides being effective steroids are cheap and this is important for a countries with low-resources like Sudan. More than one third of patients were treated conservatively, this goes with what had been recommended in the non-intervention approach [37].

Splenectomy was performed in two patients only. Kim and colleagues in a recent report had shown a high remission rate of chronic ITP in children with time. The authors suggested to delay the splenectomy for 4-5 years as long as the quality of life is not affected by the thrombocytopenia and/or therapeutic medications [35]. This suggestion might contribute in decreasing the cost associated with ITP treatment. A study had found that procedures and clinically significant bleeding were associated with higher cost when patients with ITP were hospitalized [38].

Chronic ITP was present in $31.9 \%$, this is high compared to $23 \%$ and $18 \%$ rate reported by two studies using the same definition [39,40,] but comparable to the rate reported from Qatar [41]. A systematic review and meta-analysis identified many factors as predictors of chronic ITP among them were: older age, absence of preceding upper respiratory infection or vaccination shortly before presentation, bleeding tendency, platelets count $>10.0-20.0 \times 10^{9} / \mathrm{L}$ and positive ANA [42]. Older age, lack of preceding upper respiratory infection, frequent bleeding episodes and the infrequent use of IVIG were present in our study group with chronic ITP.

\section{Conclusion}

Sudanese children with ITP have many similarities in their clinical presentation like those reported in the literature, however they were more prone to develop major hemorrhage, subconjunctival hemorrhage and a chronic course of the disease. Implementation of more recent ITP guidelines are necessary to minimize certain laboratory tests and diagnostic procedure to help in cost reduction.

\section{Competing Interests}

The authors declare that they have no competing interest.

\section{Author Contributions}

Fathelrahman Elawad Ahmed: Contributed conception and design of the study. Also he analyzed and interpreted the data and drafted the manuscript.

Egbal Hussien Younies: Contributed in the study design, data collection, data analysis and interpretation and initial drafting of the manuscript. Both authors had approved the final draft of the manuscript.

\section{References}

1. Harrington WJ, Minnich V, Hollingsworth JW, Moore CV (1990) Demonstration of a thrombocytopenic factor in the blood of patients with thrombocytopenic purpura. 1951. J Lab Clin Med 115: 636-645.

2. Rodeghiero F, Stasi R, Gernsheimer T, Michel M, Provan D, et al. (2008). Standardization of terminology; definitions and outcome criteria in immune thrombocytopenic purpura of adults and children: report from an international working group. Blood 2113: 2386-2393.

3. Zeller B, Helgestad J, Hellebostad M, Kolmannskog S, Nystad T, et.al. (2000) Immune thrombocytopenic Purpura in Childhood in Norway: a prospective, population-based registration. Pediatr Haematol Oncol 17: 551-558.

4. Nugent DJ (2006) Immune thrombocytopenic purpura of childhood. Hematology Am Soc Hematol Educ Program 97-103.

5. British Committee for Standards in Haematology General Haematology Task Force (2003) Guidelines for the investigation and management of idiopathic thrombocytopenic purpura in adults, children and in pregnancy. $\mathrm{Br} J$ Haematol 120: 574-596.

6. Kühne T, Buchanan GR, Zimmerman S, Michaels LA, Kohan R, et al (2003) A prospective comparative study of 2540 infants and children with newly diagnosed idiopathic thrombocytopenic purpura (ITP) from the Intercontinental childhood ITP Study Group. J Pediatr 143: 605-608.

7. Kühne T, Berchtold W, Michaels LA, Wu R, Donato $H$, et al. (2011) Intercontinental Cooperative ITP Study Group. Newly diagnosed immune thrombocytopenia in children and adults: a comparative prospective observational registry of the Intercontinental Cooperative Immune Thrombocytopenia Study Group. Haematologica 96: 1831-1837.

8. Neunert C, Lim W, Crowther M, Cohen A, Solberg L Jr, et al. (2011) The American Society of Hematology 2011 evidence-based practice guideline for immune thrombocytopenia. Blood 117: 4190-4207.

9. Saleh MN, Gutheil J, Moore M, Bunch PW, Butler J, et al. (2000) A pilot study of the anti-D monoclonal antibody rituximab in patients with refractory immune thrombocytopenia. SeminOncol 2: 99-103.

10. Bussel JB, Buchanan GR, Nugent DJ, Gnarra DJ, Bomgaars LR, et al. (2011) A randomized, double-blind study of romiplostim to determine its safety and efficacy in children with immune thrombocytopenia. Blood 118: 28-36.

11. Sutor $\mathrm{AH}$, Harms A, Kaufmehl K (2001) Acute immune thrombocytopenia (ITP) in childhood: retrospective and prospective survey in Germany. Semin Thromb Hemost 27: 253-267.

12. Donato H, Picón A, Martinez M, Rapetti MC, Rosso A, et al. (2004) Demographic data, natural history, and prognostic factors of idiopathic thrombocytopenic purpura in children, a multicentered study from Argentina. Pediatr Blood Cancer 52: 491-496.

13. Fogarty PF, Segal JB (2007) The epidemiology of immune thrombocytopenic purpura. Curr Opin Hematol 14: 515-519.

14. Yong M, Schoonen WM, Li L, Kanas G, Coalson J, et al. (2010) Epidemiology of pediatric immune thrombocytopenia in the general practice research database. Br J Haematol149: 855-864

15. Jonville-Béra AP, Autret E, Galy-Eyraud C, Hessel L (91996) Thrombocytopenic purpura after mumps, measles and rubella vaccination: A retrospective survey by the French Regional Pharmcovigilance Centres and Pasteur-Merieux serums et vaccines. Pediatr Infect Dis J 15: 44-48. 
Citation: Elawad Ahmed F, Younies EH (2016) Demographic and Clinical Charachteristics of Immune Thrombocytopenia in Sudanese Children. Int J Pediatr Neonat Care 2: 117. doi: https://doi.org/10.15344/2455-2364/2016/117

Page 4 of 4

16. Beeler J, Varricchio F, Wise R (1996) Thrombocytopenia after immunization with measles vaccines: review of the vaccine adverse events reporting system (1990-1994). Pediatr Infect Dis J 15: 84-88

17. Hsieh Y I, Lin L H (2010) Thrombocytopenic purpura following vaccination in early childhood : experience of a medical center in the past two decades. J Chin Med Assoc 73: 634-637.

18. Alam MM (2014) Idiopathic thrombocytopenic purpura in children: a 10 years experience at tertiary care hospital. J Pak Med Assoc 64: 1358-1362.

19. Kühne $\mathrm{T}$, Imbach $\mathrm{P}$, Bolton-Maggs $\mathrm{PH}$, Berchtold $\mathrm{W}$, Blanchette $\mathrm{V}$, et al (2001) For the International Childhood ITP Study Group. Newly diagnosed idiopathic thrombocytopenic purpura in childhood: an observational study. Lancet 358: 2122-2155.

20. Zeller B, Helgestad J, Hellebostad M, Kolmannskog S, Nystad T, et al (2000) Immune thrombocytopenic Purpura in Childhood in Norway: a prospective, population-based registration. Pediatr Haematol Oncol 17: 551-558.

21. Heitink-Pollé KM, Nijsten J, Boonacker CW, de Haas M, Bruin MC (2014) Clinical and laboratory predictors of chronic immune thrombocytopenia in children: a systematic review and meta-analysis. Blood 124: 3295-3307.

22. Zeller B, Rajantie J, Hedlund-Treutiger I, Tedgård U, Wesenberg F, et al. (2005) Childhood idiopathic thrombocytopenic purpura in the Nordic countries: epidemiology and predictors of chronic disease. Acta Paediatr 94: 178-184.

23. Kühne T, Buchanan GR, Zimmerman S, Michaels LA, Kohan R, et al. (2003) A prospective comparative study of 2540 infants and children with newly diagnosed idiopathic hrombocytopenic purpura (ITP) from the Intercontinental Childhood ITP Study Group. J Pediatr; 143: 605.

24. Sfaihi L, Kassar O, Medhaffar M, Kamoun T, Hadiji S, et al. (2014) [Primary immune thrombocytopenia in childhood: a regional study in the south of Tunisia]. Tunis Med 92: 219-223.

25. García-Stivalet LA, Muñoz-Flores A, Montiel-Jarquín AJ, Barragán-Hervella RG, Bejarano-Huertas R, et al. (2014) [Clinical analysis of 200 cases of idiopathic thrombocytopenic purpura]. Rev Med Inst Mex Seguro Soc 52: 322-325

26. Medeiros D, Buchanan GR (1998) Major hemorrhage in children with idiopathic thrombocytopenic purpura: immediate response to therapy and long-term outcome.J Pediatr 1133: 334-339.

27. Tarantino MD, Danese M, Klaassen RJ, Duryea J, Eisen M, et al. (2016) Hospitalizations in pediatric patients with immune thrombocytopenia in the United States. Platelets 27: 472-478.

28. Zhou F, Xu Y, Zhang Z, Wu X, Jin R (2015) Severe Hemorrhage in Chinese Children With Immune Thrombocytopenia. J Pediatr Hematol Oncol 37: e158-161.

29. Moussalem M, Yassine N (2003) Immune thrombocytopenic purpura in childhood: a Lebanese perspective. Mol Immunol 39: 1105-1107.

30. Flores A, Buchanan GR (2016) Occult hemorrhage in children with severe ITP. Am J Hematol 91: 287-290.

31. Elalfy M, Elbarbary N, Khaddah N, Abdelwahab M, El Rashidy F, et al. (2010) Intracranial hemorrhage in acute and chronic childhood immune thrombocytopenic purpura over a ten-year period: an Egyptian multicenter study. Acta Haematol 123: 59-63.

32. Sodhi PK, Jose R (2003) Subconjunctival hemorrhage: the first presenting clinical feature of idiopathic thrombocytopenic purpura. Jpn J Ophthalmol 47: $316-318$

33. Jung JY, O AR, Kim JK, Park M (2016) Clinical course and prognostic factors of childhood immune thrombocytopenia: single center experience of 10 years. Korean J Pediatr 59: 335-340

34. Neunert C, Noroozi N, Norman G, Buchanan GR, Goy J, Nazi I, et al. (2015) Severe bleeding events in adults and children with primary immune thrombocytopenia: a systematic review. J Thromb Haemost 13: 457-464.

35. Kim CY, Lee EH, Yoon HS (2016) High Remission Rate of Chronic Immune Thrombocytopenia in Children: Result of 20-Year Follow-Up. Yonsei Med J 57: 127-131.
36. Stefan DC, Gwessels G (2008) A survey of the management of idiopathic thrombocytopenic purpura in South Africa : Do we need guidelines for developing countries? SAJCH 2: 15-18.

37. Medeiros, Desiree, Buchanan, George R(2000) Idiopathicthrombocytopenic purpura: beyond consensus. Current Opnion in Pediatric 12: 4-9.

38. Glanz J, France E, Xu S, Hayes T, Hambidge S (2008) A populationbased, multisite cohort study of the predictors of chronic idiopathic thrombocytopenic purpura in children. Pediatrics 121: e506-512.

39. Robb LG, Tiedeman K (1990) Idiopathic thrombocytopenic purpura: predictors of chronic disease. Arch Dis Child 65: 502-506.

40. Al-Mulla N, Bener A, Amer A, Abu Laban M (2009) Idiopathic thrombocytopenic purpura in childhood : a population, based study in Qatar. J Pediatr (Rio J) 85: 269 -272. 